\title{
Knowledge Levels, Attitude and Beliefs of Men towards the Digital Rectal Examinations (DRE): A study in Trinidad
}

Philip C. Onuoha

The University of the West Indies, philip.onuoha@sta.uwi.edu

Gloria Mootoo-Ramdeen

University of the West Indies, gloria.mootoo-ramdeen@sta.uwi.edu

Melany Romany

University of the West Indies, m.Romany@myuwi.sta.edu

G La Fleur-Roseman

University of the West Indies, G.LaFleur-Roseman@myuwi.sta.edu

J Roopnarine

University of the West Indies, J.Roonarine@myuwi.sta.edu

See next page for additional authors

Follow this and additional works at: https://nsuworks.nova.edu/ijahsp

Part of the Public Health and Community Nursing Commons

\section{Recommended Citation}

Onuoha PC, Mootoo-Ramdeen G, Romany M, La Fleur-Roseman G, Roopnarine J, Diaspia-Murrell D, et al. Knowledge Levels, Attitude and Beliefs of Men towards the Digital Rectal Examinations (DRE): A study in Trinidad. The Internet Journal of Allied Health Sciences and Practice. 2020 Jan 01;18(3), Article 12.

This Manuscript is brought to you for free and open access by the College of Health Care Sciences at NSUWorks. It has been accepted for inclusion in Internet Journal of Allied Health Sciences and Practice by an authorized editor of NSUWorks. For more information, please contact nsuworks@nova.edu. 


\title{
Knowledge Levels, Attitude and Beliefs of Men towards the Digital Rectal Examinations (DRE): A study in Trinidad
}

\begin{abstract}
Background: Trinidad and Tobago have been ranked as having one of the highest cancer mortality rates in the Caribbean. Prostate cancer was identified as the most common cancer in men, with a higher mortality than any other cancer. At least 1 in 9 men in Trinidad and Tobago will be diagnosed with prostate cancer during his lifetime. Purpose: The purpose of this study is to determine knowledge levels, attitudes, and beliefs of men aged 40 years and over regarding digital rectal examination (DRE). The investigators considered this crucial following the scourge of prostate cancer in Trinidad and Tobago and an apparent lack of the use of the DRE, a noted method of screening for the condition for early detection. Methods: A cross-sectional descriptive study was undertaken using 216 men who were at least 40 years old and who gave their informed consent; these men were attending a central mall in Trinidad in the month of April 2018 when the data was collected. Data was collected using the researchers' designed, self-administered questionnaire and analysed using SPSS version 20. Result: Results indicate that most men (95.8\%) are knowledgeable/very knowledgeable about DRE. Similarly, most (64.6\%) of the men have favourable/very favourable attitudes towards DRE while $59.3 \%$ of them indicated that their beliefs have little or major influence regarding their participation in DRE. It also showed that the men's beliefs are associated with their ethnicity (pDiscussion/Recommendation/Conclusion: The findings suggest that perhaps the attitudes and beliefs of men aged 40 years and over attending this mall are better predictors of intentions than their knowledge. This needs to be explored further given the need to curb the prevalence of prostate cancer amongst men in Trinidad and Tobago.
\end{abstract}

\section{Author Bio(s)}

Philip C. Onuoha, PhD, MPH, BSc, RNT, RN is a Senior Lecturer at the School of Nursing, Faculty of Medical Sciences, University of the West Indies, St. Augustine, Trinidad and Tobago.

Glorida Mootoo-Rameen is an assistant lecturer at the UWSoN and a registered nurse.

Melany Romany, G. La Fleur-Rossemn, J. Roopnarine, D. Diasspia, K. Martin-Murrel, and H. Hypolite were all students of the UWI School of Nursing at the time this study was conducted.

\section{Acknowledgements}

We acknowledge the research participants as well as the Trincity Mall owners for their assistance in this project. We remain indebted to them.

\section{Authors}

Philip C. Onuoha, Gloria Mootoo-Ramdeen, Melany Romany, G La Fleur-Roseman, J Roopnarine, D DiaspiaMurrell, K Martin-boucaud, and P Hypolite 


\title{
IJAHSP \\ The Internet Joutnal of Allied Health Sciences and Practice
}

Dedicated to allied health professional practice and education

Vol. 18 No. 3 ISSN 1540-580X

\section{Knowledge Levels, Attitude and Beliefs of Men Towards the Digital Rectal Examinations (DRE): A Study in Trinidad.}

\author{
Philip C. Onuoha \\ Gloria Mootoo-Ramdeen \\ Melany Romany \\ G. La Fleur-Roseman \\ J. Roopnarine \\ D. Diaspia-Murrell \\ K. Martin-Boucaud \\ P. Hypolite
}

University of the West Indies

Trinidad and Tobago

\begin{abstract}
Background: Trinidad and Tobago have been ranked as having one of the highest cancer mortality rates in the Caribbean. Prostate cancer was identified as the most common cancer in men, with a higher mortality than any other cancer. At least 1 in 9 men in Trinidad and Tobago will be diagnosed with prostate cancer during his lifetime. Purpose: The purpose of this study is to determine knowledge levels, attitudes, and beliefs of men aged 40 years and over regarding digital rectal examination (DRE). The investigators considered this crucial following the scourge of prostate cancer in Trinidad and Tobago and an apparent lack of the use of the DRE, a noted method of screening for the condition for early detection. Methods: A cross-sectional descriptive study was undertaken using 216 men who were at least 40 years old and who gave their informed consent; these men were attending a central mall in Trinidad in the month of April 2018 when the data was collected. Data was collected using the researchers' designed, self-administered questionnaire and analysed using SPSS version 20. Result: Results indicate that most men (95.8\%) are knowledgeable/very knowledgeable about DRE. Similarly, most (64.6\%) of the men have favourable/very favourable attitudes towards DRE while $59.3 \%$ of them indicated that their beliefs have little or major influence regarding their participation in DRE. It also showed that the men's beliefs are associated with their ethnicity $(p<0.03)$. Discussion/Recommendation/Conclusion: The findings suggest that perhaps the attitudes and beliefs of men aged 40 years and over attending this mall are better predictors of intentions than their knowledge. This needs to be explored further given the need to curb the prevalence of prostate cancer amongst men in Trinidad and Tobago.
\end{abstract}

Keywords: digital rectal examination, prostate cancer, knowledge, behaviour, Caribbean

C The Internet Journal of Allied Health Sciences and Practice, 2020 


\section{INTRODUCTION}

The World Health Organization has declared that cancer is rapidly becoming, a universal predicament with an estimated 14 million men diagnosed with cancer in 2012 and that 22 million will be diagnosed by $2032 .{ }^{1}$ Men are therefore at risk of developing prostate cancer, and it is projected that at least 1 in 9 men will be diagnosed with prostate cancer during his lifetime. It is also estimated that about eighty percent of men upon reaching the age of eighty will present with prostate cancer cells. ${ }^{2}$

According to the Pan American Health Organization (PAHO), the World Health Organization (WHO), and Cancer in the Americas, Trinidad and Tobago was ranked as having one of the highest cancer mortality rates in the Caribbean. Prostate cancer was identified as the most common cancer in men, with higher mortality than any other cancer in Trinidad and Tobago. ${ }^{3}$ Further, the WHO reported that in 2014, prostate cancer accounted for 34.8 percent of the 1,100 cancer-related death in males in Trinidad and Tobago, compared to an estimated number of incident cases for prostate cancer for 2012 at 704 . There were almost 500 more cases of prostate cancer when compared to its nearest rival of colorectal cancer in men, which is the second highest incidence rate of cancer in this country. ${ }^{4}$

However, the Digital Rectal Examination (DRE) is used for the early diagnosis of intestinal bleeding, anorectal pain, and both benign and malignant diseases of the prostate. ${ }^{4}$ Research shows that the DRE is an integral component of the assessment of the prostate gland and has been an important tool in aiding with the diagnosis of prostate cancer, though this examination is often overlooked and undervalued. ${ }^{5}$ Men in Trinidad and Tobago have continued to avoid this early screening test despite the disturbing incidence rates. ${ }^{3}$ Previous studies have indicated that age, race, and family history have all been associated with the incidence and progression of prostate cancer. ${ }^{22,23}$ Further, the main reasons underlying men's late presentation to health services include masculinity norms, lack of awareness and knowledge of early stage prostate cancer, and cultural beliefs and practices in Trinidad and Tobago. ${ }^{24}$

The knowledge, attitudes and beliefs of men, particularly those at risk of developing prostate cancer, are deemed crucial in understanding whether or not they would take the desired action of DRE for this condition. 5,6 In Nigeria, poor knowledge was reported among men aged 40 years and over. 7,8 The situation is same in Jamaica, among African-Americans, in Italy; and in Uganda. ${ }^{9-10}$ This theory is tested in this study in Trinidad, as there is no empirical evidence on the knowledge, attitudes, and beliefs of men aged 40 years and over regarding the DRE.

It is therefore the intention of the investigators to describe (a) the knowledge levels of men aged 40 year and over, (b) the extent to which they have favourable attitudes, and (c) the extent to which their beliefs influence their behaviours regarding DRE.

\section{Objectives of the Study}

1. To determine the knowledge levels of men aged 40 years and over in Trinidad, regarding the DRE.

2. To determine whether men aged 40 years and over in Trinidad have favourable or unfavourable attitudes regarding the DRE.

3. To explore the beliefs of men aged 40 years and over in Trinidad regarding the DRE.

4. To determine if men's (a) knowledge levels, (b) attitudes and (c) beliefs regarding the DRE are associated with their social demographic characteristic namely: (i) age, (ii) religion, (iii) ethnicity, (iv) marital status and (v) educational level in Trinidad.

\section{Research Questions}

1. What are the knowledge levels of men aged 40 years and over in Trinidad regarding the DRE?

2. Do men aged 40 years and over in Trinidad have favourable or unfavourable attitudes regarding DRE?

3. What are the beliefs of men aged 40 years and over in Trinidad regarding the DRE?

4. Are the (a) knowledge levels, (b) attitudes and (c) beliefs of men aged 40 years and over regarding the DRE associated with (i) age, (ii) religion, (iii) ethnicity, (iv) marital status and (v) educational level in Trinidad?

\section{Conceptual Framework: Adapting the Theory of Planned Behaviour}

The Theory of Planned Behaviour (TPB) is aimed at predicting an individual's intention to engage in a behaviour 12. It was intended to explain all behaviours over which individuals can exert self-control. It suggests that individual behaviour is driven by behaviour intentions, where behaviour intentions are a function of three determinants: an individual's attitude toward the behaviour, subjective norms, and perceived behavioural control. We believe the TPB model can help to determine if the knowledge, attitudes, and beliefs (intentions) of men aged 40 years and over in Trinidad can be used to explain the extent to which it can influence their behaviour towards digital rectal examination. ${ }^{12}$ 
Behavioural beliefs link the behaviour of interest to expected outcomes; normative beliefs refer to the supposed behavioural expectations of individuals or groups about whether or not significant people in their life would approve or disapprove of their behaviour. ${ }^{6}$ On the other hand, control beliefs refer to an individual's belief that he or she possesses the necessary resources, skills, and opportunities to aid or inhibit performance of a behaviour. ${ }^{6}$

Here, the interest is men's knowledge, attitude, and beliefs towards DRE. The expectation is that this will assist in establishing whether this group of at-risk men are influenced positively or negatively towards accessing the DRE. The first influence is the attitude towards the behaviour. In this phase they weigh the benefits and consequences of having the DRE.

The subjective norm refers to the individual's belief about how their significant others will view their behaviour. In this stage, men face issues that may influence the opinion of the behaviour (DRE) by questioning themselves on how others would see their decision to undergo a DRE. This will include whether they will be supported or ridiculed since men's health issues have been stereotyped..$^{13}$

Perceived behavioural control refers to people's perceptions of the extent to which performance of the behaviour is easy or difficult. ${ }^{6}$ It increases when individuals perceive they have more resources and confidence in themselves. This entails the men's beliefs about the presence of factors internal or external that may facilitate or impede the behaviour. This would lead to behaviour intention. ${ }^{6}$ The best predictor of any behaviour is an intention. The intention is the mental representation of a person's readiness to perform a given behaviour, and it is the immediate precursor of behaviour. ${ }^{6}$

The digital rectal examination (DRE) as an integral component of the assessment of the prostate gland that aids with the diagnosis of prostate cancer. This is often overlooked or undervalued ${ }^{5}$ Men in Trinidad and Tobago have continued to avoid this early screening test despite the incidence rates among men. ${ }^{3}$

There are several factors that can influence men's choice of having the DRE. These were identified as their knowledge, attitude, and cultural beliefs which are incorporated in their socio-demographics. Overall, the more favourable an individual's attitude, combined with the subjective norm and the individual's control, the stronger is the person's intention to perform the behaviour. This means that the more positive men's knowledge, attitude, and belief towards the DRE are, the greater is their possibility of accessing and consenting to having the DRE done. This forms the crux of this study. We aim to determine from men aged 40 years or more (a) how knowledgeable they are (b) how favourable their beliefs are and (c) how favourable are their attitudes, towards DRE in Trinidad and Tobago.

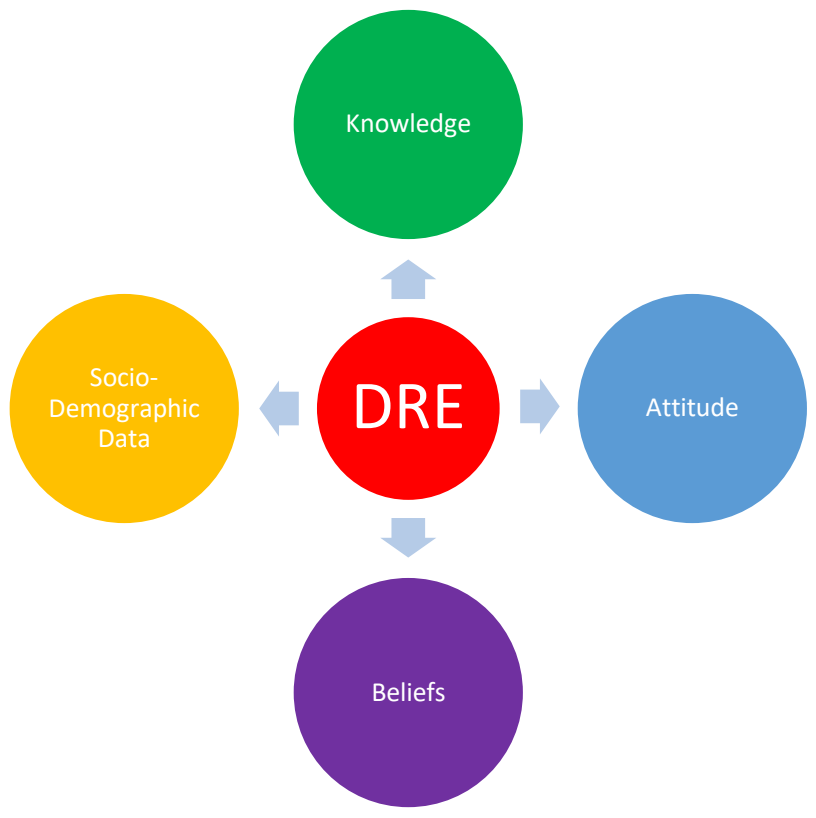

Figure 1: Relationship between the independent and dependant variables. 


\section{METHODOLOGY \\ Design}

A cross-sectional descriptive study was undertaken as we attempted to get information on men aged 40 years and over regarding DRE at a single point in time, in order to determine the relationship between DRE practice of these men and their knowledge levels, attitudes, and beliefs. ${ }^{14,15}$

\section{Population and Setting}

The subjects were men aged 40 years and older visiting Trincity Mall in Trinidad on April 21 and 28, 2018, from 1 to 6 pm. Attendance at this mall was considered central as all races and all socio-economic classes attend the mall without prohibition of any kind in Trinidad and Tobago. The Central Statistical Office (CSO) of Trinidad and Tobago estimates that the male population in Trinidad and Tobago is 666,305 . It also estimates that 43,454 is over the age of forty, representing approximately $15 \%$ of the population. Calculating from this estimation and using the Raosoft sample estimation formulae, $N \times 1\left((N-1) E^{2}+x\right)$ at a $95 \%$ confidence level, the recruitment of 216 research participants was deemed adequate. ${ }^{12}$ We utilized a purposive sample because a deliberate attempt was made to target only men 40 years of age and over. All qualified subjects who visited the mall on the days in April and who volunteered to participate were recruited until we got the desired number of 216 subjects.

\section{Instrument and Administration}

A questionnaire was constructed by the researchers based on literature and on the researchers' understanding of the nuances of the subject matter (DRE). For example, the 7 items that make up knowledge contained items related to the respondents' understanding of DRE, place of screening, who does the screening, and risks associated with the test, while the 7 items on attitudes elicited information from respondents on their feelings related to DRE, any preference on what the gender of who can perform the test for them, and if they could encourage others to do the screening test. On the belief, the instrument explored the respondents' understanding of their family and religious and traditional influences in their determination to undertake DRE. The instrument was constructed Likert-like for easy understanding and responses. It consisted of twenty-seven (27) items divided into four parts:

(i) Socio-demographic data (6) items

(ii) Knowledge (7) items

(iii) $\quad$ Attitude (7) items

(iv) Beliefs (7) items

It was self-administered to the willing and consenting participants and was collected immediately after completion. The instrument has a Cronbach's alpha result of 0.72 ; having ensured that the instrument had face and content validity including congruence with literature, it was deemed appropriate. ${ }^{15}$ It took about 10 minutes to complete. Data was manually collated but analysed using the Statistical Package for the Social Sciences (SPSS) version 20.

\section{Ethical Considerations}

Ethical approval was obtained from the University of the West Indies Ethics Committee and from the Management of the Trincity Mall. A cover letter explaining the purpose of the study and seeking permission to administer copies of the questionnaire to males was forwarded to the owners of Trincity Mall. The researchers obtained informed consent from the research participants. It should be noted that approval from the University of the West Indies, included approval of the written informed consent for all research participants.

\section{RESULTS}

Socio-demographic Data of Men in the Study.

Two hundred and sixteen (216) men participated in the survey. Approximately half of the sample was within the age group 40-50 years and were married. Married men accounted for $56.5 \%$ of the sample. African respondents represented $50 \%$ of the sample while East Indian represented $28.7 \%$. The majority of the participants were of the Christian faith (69.9\%) while $76.4 \%$ reported that their highest level of education attained was secondary or tertiary (see Table 1). 
Table 1. Socio-demographic characteristics among Trinidadian men

\begin{tabular}{|c|c|c|}
\hline \multicolumn{3}{|c|}{ Demographic Data $(n=216)$} \\
\hline Variables & $\mathrm{n}$ & $\mathrm{n}(\%)$ \\
\hline \multicolumn{3}{|c|}{ Age } \\
\hline $40-45$ & 70 & 32.4 \\
\hline $46-50$ & 39 & 18.1 \\
\hline $51-55$ & 28 & 13 \\
\hline $56-60$ & 42 & 19.4 \\
\hline $61-65$ & 16 & 7.4 \\
\hline 66 and over & 21 & 9.7 \\
\hline \multicolumn{3}{|c|}{ Marital Status } \\
\hline Single & 56 & 25.9 \\
\hline Married & 122 & 56.5 \\
\hline Divorce & 26 & 12.0 \\
\hline Common Law & 12 & 5.6 \\
\hline \multicolumn{3}{|c|}{ Ethnicity } \\
\hline African & 108 & 50.0 \\
\hline East Indians & 62 & 28.7 \\
\hline Mixed & 43 & 19.9 \\
\hline Other & 3 & 1.4 \\
\hline \multicolumn{3}{|c|}{ Religion } \\
\hline Christian & 151 & 69.9 \\
\hline Hindu & 34 & 15.7 \\
\hline Islam & 11 & 5.1 \\
\hline Other & 20 & 9.3 \\
\hline \multicolumn{3}{|c|}{ Educational Level } \\
\hline Primary & 39 & 18.1 \\
\hline Secondary & 94 & 43.5 \\
\hline Tertiary & 71 & 32.9 \\
\hline Vocational & 12 & 5.6 \\
\hline
\end{tabular}

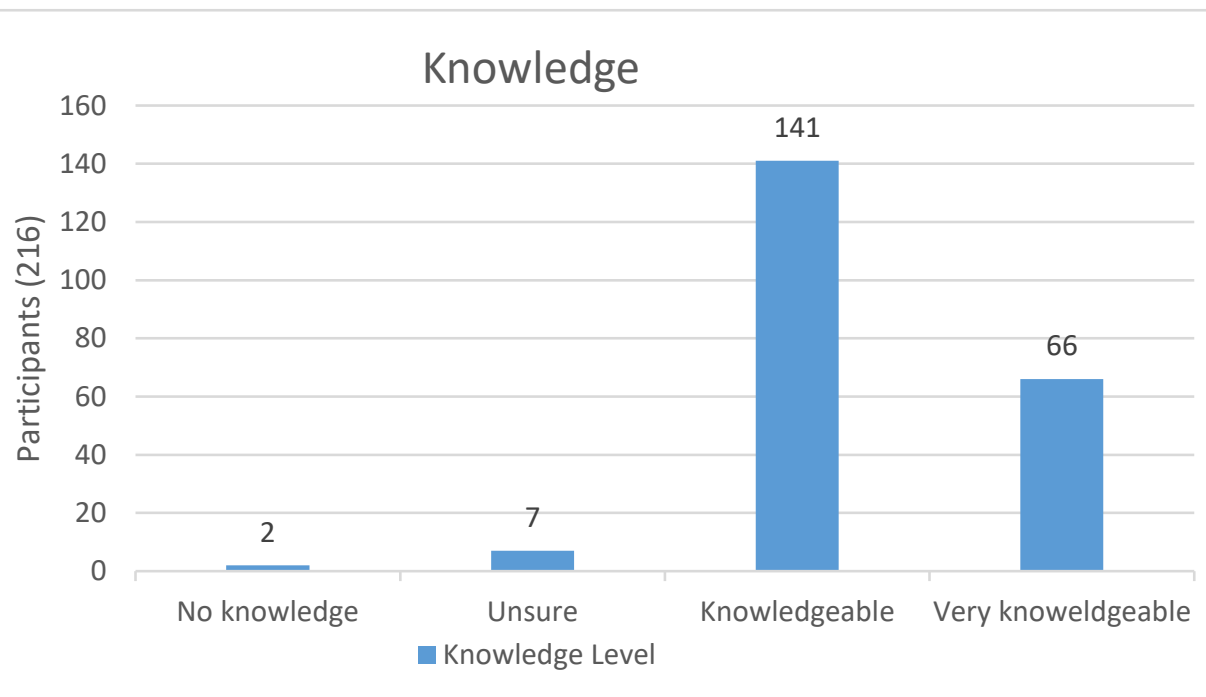

Figure 2. Knowledge level of the participants regarding the DRE. This figure shows that $95.8 \%$ (207) participants indicated having knowledge (knowledgeable and very knowledgeable) of DRE. 


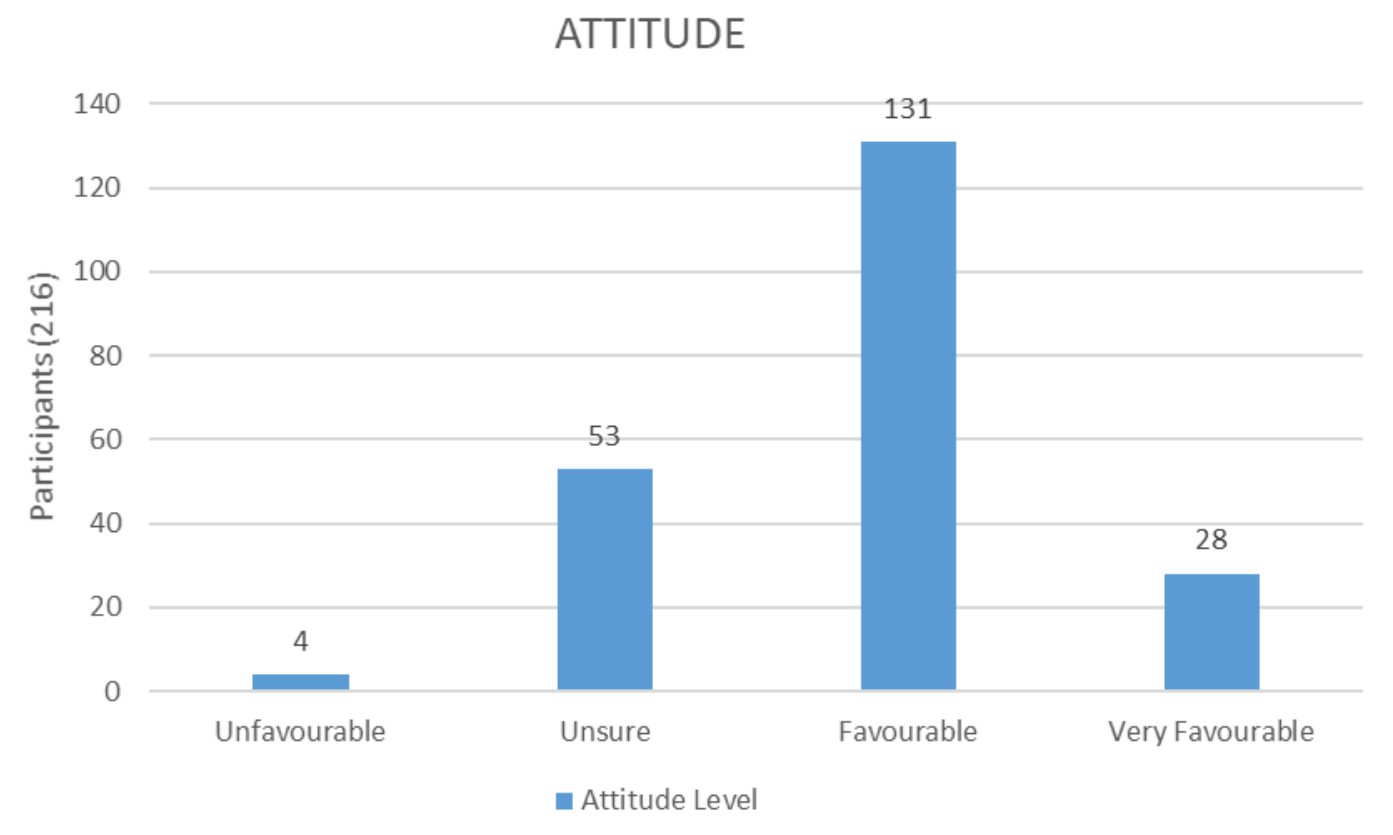

Figure 3. Attitude level of the participants regarding the DRE. This figure shows that $73.6 \%$ (159) indicated favourable or very favourable attitudes towards DRE.

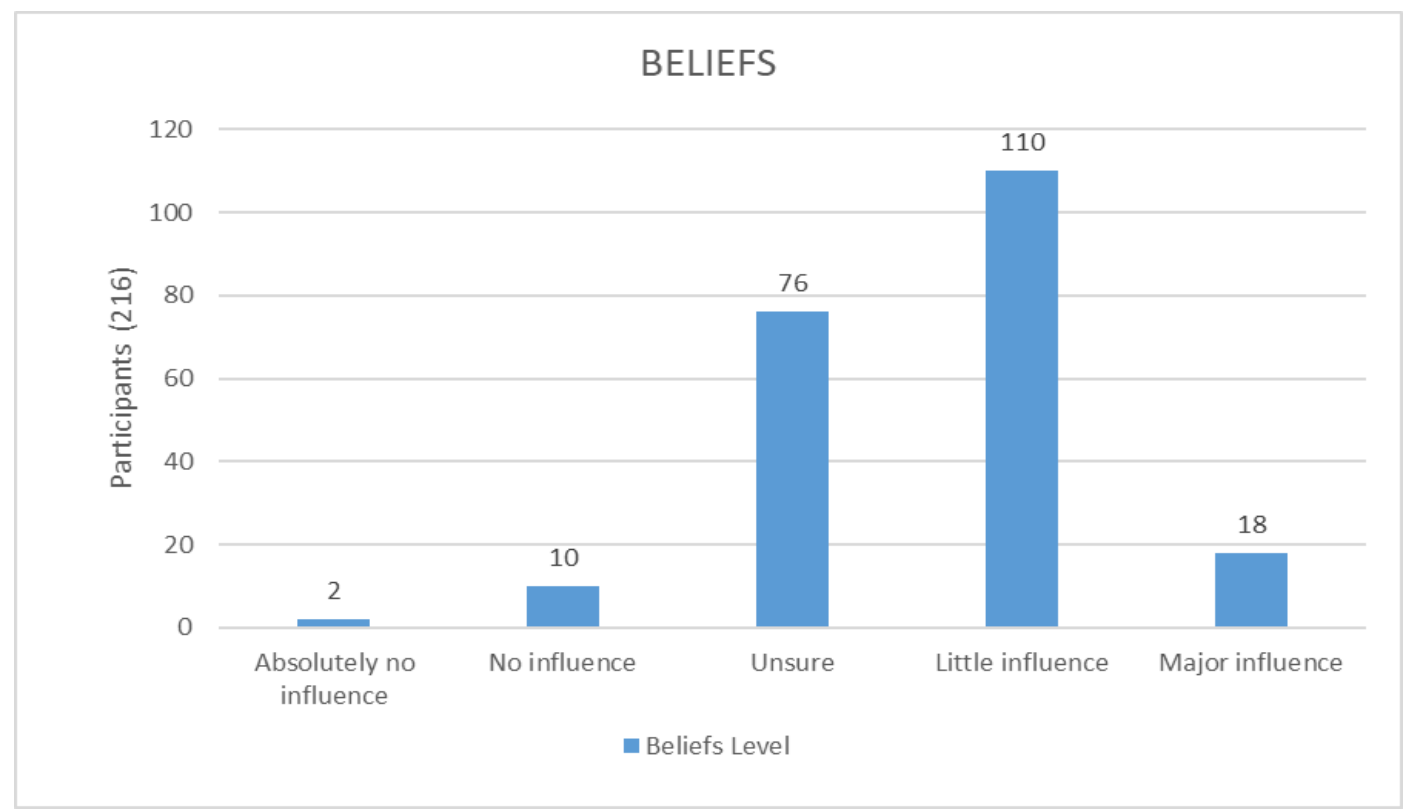

Figure 4: Beliefs of the participants regarding the DRE; $59.3 \%$ (128) participants indicated their beliefs have little influence or major influence in them regarding DRE 
Table 2. Association between knowledge and socio-demographic data.

\begin{tabular}{|l|l|l|l|}
\hline Variable & Unknowledgeable & Knowledgeable & P-Value \\
\hline Age & & & 0.171 \\
\hline$\leq 50$ years & $7(6.42)$ & $102(93.85)$ & \\
\hline$>50$ years & $2(1.87)$ & $105(98.13)$ & \\
\hline Religion & & & 0.180 \\
\hline Christian & $9(5.96)$ & $142(94.04)$ & \\
\hline Hindu & $0(0.00)$ & $34(100.00)$ & \\
\hline Other & $0(0.00)$ & $31(100.00)$ & \\
\hline Education & & & 1.000 \\
\hline Primary/ Vocational & $2(3.92)$ & $49(96.08)$ & \\
\hline Secondary/ Tertiary & $7(4.24)$ & $158(95.76)$ & \\
\hline Marital Status & & & 0.552 \\
\hline Single & $3(5.36)$ & $53(94.64)$ & \\
\hline Married & $4(3.28)$ & $118(96.72)$ & \\
\hline Divorced & $1(3.85)$ & $25(96.15)$ & \\
\hline Common- Law & $1(8.33)$ & $11(91.67)$ & \\
\hline Ethnicity & & & 1.000 \\
\hline African & $5(4.63)$ & $103(95.37)$ & \\
\hline East Indian & $2(3.23)$ & $60(96.77)$ & \\
\hline Mixed & $2(4.65)$ & $31(95.35)$ & \\
\hline Other & $0(0.00)$ & $3(100.00)$ & \\
\hline
\end{tabular}

Table 2 indicates that there is no statistical association between the knowledge levels of men aged 40 years and over attending the Trincity Mall in Trinidad and Tobago and their demography. Similarly, table 4 indicates no association between the beliefs and their demography. In table 3 however, the attitudes of men 40 years and over in Trinidad and Tobago are associated with their demographic characteristics ( $p \leq 0.03$ ).

Table 3. Association between attitude and socio-demographic data.

\begin{tabular}{|l|l|l|l|}
\hline Variable & Unfavourable & Favourable & P-Value \\
\hline Age & & & 0.218 \\
\hline$\leq 50$ & $33(30.28)$ & $76(69.72)$ & \\
\hline Religion & $24(22.43)$ & $83(77.57)$ & \\
\hline Christian & & & 0.410 \\
\hline Hindu & $36(23.84)$ & $115(76.16)$ & \\
\hline Other & $11(32.35)$ & $23(67.65)$ & \\
\hline Education & $10(32.26)$ & $21(67.74)$ & \\
\hline Primary/ Vocational & $10(19.61)$ & & 0.275 \\
\hline Secondary/ Tertiary & $47(28.48)$ & $118(71.52)$ & \\
\hline Marital Status & & & 0.245 \\
\hline Single & $17(30.36)$ & $39(69.64)$ & \\
\hline Married & $35(28.69)$ & $87(71.31)$ & \\
\hline Divorced & $4(15.38)$ & $22(84.62)$ & \\
\hline Common- Law & $1(8.33)$ & $11(91.67)$ & \\
\hline Ethnicity & & & 0.030 \\
\hline African & $22(20.37)$ & $86(79.63)$ & \\
\hline East Indian & $25(40.32)$ & $37(59.68)$ & \\
\hline Mixed & $10(23.26)$ & $33(76.74)$ & \\
\hline Other & $0(0.00)$ & $3(100.00)$ & \\
\hline
\end{tabular}


Table 4. Association between beliefs and socio-demographic data

\begin{tabular}{|l|l|l|l|}
\hline Variable & No Influence & Influence & P-Value \\
\hline Age & & & 0.782 \\
\hline$\leq 50$ years & $43(39.45)$ & $66(60.55)$ & \\
\hline$>50$ years & $45(42.06)$ & $62(57.94)$ & \\
\hline Religion & & & 0.122 \\
\hline Christian & $59(39.07)$ & $92(60.93)$ & \\
\hline Hindu & $19(55.88)$ & $15(44.12)$ & \\
\hline Other & $10(32.26)$ & $21(67.74)$ & \\
\hline Education & & & 0.871 \\
\hline Primary/ Vocational & $20(39.22)$ & $31(60.78)$ & \\
\hline Secondary/ Tertiary & $68(41.21)$ & $97(58.79)$ & \\
\hline Marital Status & & & 0.153 \\
\hline Single & $18(32.14)$ & $38(67.86)$ & \\
\hline Married & $49(40.16)$ & $73(59.84)$ & \\
\hline Divorced & $15(57.69)$ & $11(42.31)$ & \\
\hline Common- Law & $6(50.00)$ & $6(50.00)$ & \\
\hline Ethnicity & & & 0.656 \\
\hline African & $40(37.04)$ & $68(62.96)$ & \\
\hline East Indian & $29(46.77)$ & $33(53.23)$ & \\
\hline Mixed & $18(41.86)$ & $25(58.14)$ & \\
\hline Other & $1(33.33)$ & $2(66.67)$ & \\
\hline & & & \\
\hline
\end{tabular}

\section{DISCUSSION}

Although we note what may be considered some of the limitations of this study, including the manner of the sampling and the sample size, our analysis suggests that $94 \%$ of the Trinidadian men involved in the study were knowledgeable and aware of the DRE. This is contrary to the study of Nigerians, where poor awareness and knowledge were factors which accounted for the Nigerian men turning a blind eye to the DRE. ${ }^{7}$ One of the major issues which deterred Jamaican men from consenting to the DRE was their knowledge competence and misconception. ${ }^{9}$ African American men in their 40s were at high risk for prostate cancer due to limited knowledge on the DRE. ${ }^{16}$ However, those who were knowledgeable did in fact consent to the DRE and were engaging in annual DREs. ${ }^{16}$

On the other hand, ignorance was indicated as the major issue affecting men's decision in consenting to the DRE among the medical professionals. ${ }^{19}$ It noted that the lack of knowledge was a result of the lack of medical advice, awareness of the importance, and relevance of the examination. For example, Nigerian men of the Yoruba tribe knew they had a prostate gland but did not view it as a body organ; hence, a DRE was not necessary. ${ }^{8}$

In Trinidad and Tobago, men displayed negative attitudes towards DRE because they viewed it as "an assault on their manhood." Further, the gender of the personnel conducting the examination was an area of concern; men experienced homophobic anxiety with male health care providers were unwilling to undergo a DRE. ${ }^{13}$

It is interesting to note that while $56.9 \%$ of our participants would consider having a DRE, many more $(72.2 \%)$ would recommend it to their peers. Given that black men strongly depended on their female relatives in making the decision to consent to a DRE, it was found in this study that more of the married men in Trinidad and Tobago accessed and consented to DRE. ${ }^{17}$

The finding that 138 men (63.9\%) were uncomfortable speaking about DRE and 161 (74.5\%) tend to support the argument that culturally, some men were fearful of having a DRE, hinting that the fear of the unknown may have been the barrier to having a DRE. Even though Jamaican and African- Canadian men resisted the DRE because of its cultural unacceptability as being associated with homosexuality, Trinidadian men believed otherwise..$^{18}$

\section{CONCLUSION}

Men in Trinidad and Tobago tend to be generally (a) knowledgeable about DRE, (b) have a positive belief about DRE and its medical significance, but (c) have poor attitudes towards DRE. This study attempted to apply the this theoretical framework. ${ }^{6}$ Prior research using the Theory of Planned Behaviour has illustrated success in mammography screening. ${ }^{20}$ The model has been used 
to study ethnicity in health behaviour and revealed a number of factors to consider when developing instruments for attitude assessment among others. ${ }^{21}$

Having established that men aged 40 years and over in Trinidad and Tobago do not attend DRE at the desired level, it is possible that this low attendance to DRE could be as a result of their attitudes given, that their knowledge levels and beliefs are higher than their attitudes. Further, this study suggests, men's attitudes are better predictors of their behaviour intentions than their knowledge or their beliefs. We recommend that more studies be undertaken to further test this assertion.

\section{REFERENCES}

1. World Health Rankings. (2017). Health Profile Trinidad and Tobago. Retrieved from http://www.worldlifeexpectancy.com/country-health-profile/trinidad-tobago.

2. WebMD. (2017, November 14). Prostate Cancer Risk Factors. Retrieved from http:///www.webmd.com/prostatecancer/guide/prostate-cancer-risk-factors

3. Julien J. (2017) "We can beat prostate cancer." The Guardian Newspaper http://m.guardian.co.tt/news/2017-09-16/\%E2\%80\%98we-can-beat-prostate-cancer\%E2\%80\%99

4. Cancer Country Profile. (2014). Trinidad and Tobago. Retrieved from http://www.who.int/cancer/countryprofiles/tto_en.pdf?ua=1

5. Walsh AL, Considine SW, Thomas AZ, Lynch TH, Manecksha RP. (2014). Digital rectal examination in primary care is important for early detection of prostate cancer: a retrospective cohort analysis study. Br J Gen Pract. 2014;64(629), e783-e787. doi:10.3399/bjgp14x682861

6. Ajzen I. The theory of planned behavior. Organ Behav Hum Decis Process. 1991;50(2), 179-211.

7. Okuku F, Orem J, Holoya J, Holoya G, De Boer C, Thompson CL, Cooney M. Prostate cancer burden at the Uganda cancer institute. J Glob Oncol. 2016 Feb 7;2(4):181-185. doi: 10.1200/JGO.2015.001040

8. Olapade-Olaopa EO, Owoaje ET, Kola L, Ladipo MM, Adebusoye L, Adedeji TG. Knowledge and perception of Nigerian men 40 years and above regarding prostate cancer. J West Afr Coll Surg. 2014 Jan-Mar;4(1):1-16

9. Morrison BF, Aiken WD, Mayhew R, Gordon Y, Odedina FT. Prostate cancer knowledge, prevention, and screening behaviors in Jamaican men. J Cancer Educ. 2017 Jun; 32(2):352-356. doi: 10.1007/s13187-016-0991-8

10. Winterich JA, Quandt SA, Grzywacz JG, Clark P, Dignan M, Stewart JH, Arcury TA. Men's knowledge and beliefs about colorectal cancer and three screenings: education, race, and screening status. Am J Health Behav. 2011 Sept; 35(5): 525-534. doi:10.5993/ajhb.35.5.2

11. Morlando M, Pelullo CP, Di Giuseppe G. Prostate cancer screening: knowledge, attitudes, and practices in a sample of men in Italy. A survey. PloS One. 2017 Oct12;12(10):e0186332. doi: 10.1371/journal.pone.0186332.

12. The (CSO) Central Statistical Office of Trinidad and Tobago. Census Reports | National Archives of Trinidad and Tobago. 2011. Retrieved from cso.gov.tt

13. Ocho ON, Green J. Perception of Prostate Screening Services among Men in Trinidad and Tobago. Sex Res Social Policy. 2013;10(3), 186-192. doi:10.1007/s13178-013-0118-5

14. Polit DF, Beck CT. Essentials of Nursing Research: Edition Appraising Evidence for Nursing Practice, $7^{\text {th }} \mathrm{ed}$. Wolters Kluwer/ Lippincott Williams \& Wilkins; 2010. 
15. Prescott-Carter K, Onuoha PC Nursing Students Levels of Satisfaction on their Clinical Experiences at a Major Caribbean Hospital. Int J Curr Adv Res. 2016;4(4):1036-1051. doi:10.21474/IJAR01

16. Nakandi $\mathrm{H}$, Kirabo M, Semugabo C, Kittengo A, Kitayimbwa P, Kalungi S, Maena J. Knowledge, attitudes, and practices of Ugandan men regarding prostate cancer. Afr J Urol. 2013 Dec;19(4):165-170. doi: 10.1016/j.afju.2013.08.001.

17. Ahiagba $\mathrm{P}$, Alexis $\mathrm{O}$, Worsley AJ. Factors influencing black men and their partners' knowledge of prostate cancer screening: a literature review. Br J Nurs. 2017 Oct 12;26(18), S14-S21. doi:10.12968/bjon.2017.26.18.s14

18. Aiken WD, Eldemire-Shearer D. Prostate cancer in Jamaica and the wider Caribbean: It is time to consider screening. West Indian Med. J. 2012 Jan;61(1):90-3. PMID: 22808573.

19. Chua ME, Lapitan MCM, Morales ML, Roque ABM, Domingo JK. 2013 Annual National Digital Rectal Exam Day: impact on prostate health awareness and disease detection. Prostate Int. 2014 Mar;2(1):31-36. doi:10.12954/pi.13039.

20. Steele SK, Porche DJ. Testing the theory of planned behavior to predict mammography intention. Nurs Res. 2005;54:332-8. doi: 10.1097/00006199-200509000-00007

21. Godin G, Kok G. The theory of planned behavior: a review of its applications to health-related behaviors. Am J Health Promot. 1996;11:87-98. DOI: 10.4278/0890-1171-11.2.87

22. Gan PH. Risk factors for prostate cancer. Rev Urol. 2002;4 (suppl 5): s3-s10. PMID: 1698606

23. Giovanucci, E, Lui Y, Platz EA, Stampfer MJ, Willet WC. Risk factors of prostate cancer incidence and progression in the health professionals follow-up study. Int J Cancer. 2009 Oct1;121(7):1571-1587. doi: 10.1002/ijc.22788.

24. King-Okoye, M. Silence Among Afro-Caribbean Men Diagnosed with Prostate Cancer in Trinidad and Tobago: A Grounded Theory Study. A thesis submitted for the degree of Doctor of Philosophy, University of Surrey; April 2018.

\section{Appendix 1: Instrument for Data Collection: KAB on DRE}

Instructions: Please tick the most appropriate response.

\section{Section 1: Socio-demographic data:}

1. What is your age group?

$$
\square \text { 40-45years } \square \text { 46-50years } \square \text { 51-59years } \square \text { 60-69years } \square 70 \text { years and over }
$$

2. What is your ethnicity?

$$
\square \text { African } \quad \square \text { East Indian } \quad \square \text { Caucasian } \quad \square \text { Mixed } \quad \square \text { Other }
$$

3. What is your marital status?

$$
\square \text { Single } \square \text { Married } \square \text { Widowed } \square \text { Divorced } \square \text { Separated } \square \text { Common law }
$$

4. What level of education have you obtained?

$$
\begin{gathered}
\square \text { Primary school } \quad \square \text { Secondary school } \quad \square \text { Associate degree } \quad \square \text { Bachelor's degree } \\
\square \text { Master's degree } \quad \square \text { Ph.D. } \quad \square \text { Never went to school }
\end{gathered}
$$


5. What is your employment status?

$$
\square \text { Employed } \quad \square \text { Unemployed } \quad \square \text { Pensioner }
$$

6. What is your religion?

$$
\square \text { Christian } \quad \square \text { Hindu } \square \text { Muslim } \square \text { Atheist } \square \text { other }
$$

\section{Section 2: Knowledge:}

1. Do you have a prostate gland?

$$
\text { 口YES } \quad \square \text { NO al don't know }
$$

2. Do you know what a Digital Rectal Examination (DRE) is?

$$
\square \text { YES } \square \text { NO }
$$

3. Which of the following describes a DRE?

ㅁlt's a quick, easy way to check the health of a man's prostate gland.

口lt is used to check the female organs. 口ult is an examination of the rectum. $\square A$ camera is used to examine the man's anus.

4. Why is a DRE done?

$\square T 0$ assess the size of the prostate and check for tumors or infection of the prostate.

口To palpate your anus. $\quad$ TTo determine the need for surgery.

$\square T 0$ check for the presence of sphincter muscle control.

5. Who performs a DRE?

$\square$ The nurse. $\quad \square$ The surgeon. $\quad \square$ The enrolled nursing assistant. $\quad$ Anaesthetist

6. Do you think that the DRE can aid in the early detection of Prostate Cancer?

$$
\square Y E S \quad \square N O \quad \square \text { I don't know }
$$

7. Do you know where you can get a DRE done?

$$
\square Y E S \quad \square N O
$$

\section{Section 3: Attitude:}

1. Should men over the age of 40 years have a DRE done?

$$
\square \text { Strongly agree } \quad \square \text { Agree } \square \text { Neutral } \square \text { Disagree } \square \text { Strongly disagree }
$$

2. How do you feel about having a DRE?

$$
\square \text { Worried } \quad \square \text { Afraid } \quad \square \text { Comfortable } \quad \square \text { Violated }
$$

(c) The Internet Journal of Allied Health Sciences and Practice, 2020 
3. What does the DRE mean to you?

$$
\text { ㅁlt's a healthy behavior alts feminine alt's too invasive alt demeans a man. }
$$

4. Would you prefer a female doctor rather than a male doctor perform your DRE?

$$
\square \mathrm{YES} \quad \square \mathrm{NO}
$$

5. Would you encourage other men to have a DRE?

$$
\triangle Y E S \quad \square N O
$$

6. Do you believe that a DRE is important to men?

$$
\square Y E S \quad \square N O
$$

7. Do you believe there is more negative associated with having a DRE done than benefits?

$$
\square Y E S \quad \square N O
$$

\section{Section 4: Cultural Beliefs:}

1. Do men in your family ever discuss having a DRE?

$$
\square Y E S \quad \square \text { NO }
$$

2. Does your religious beliefs influence having a DRE?

$$
\text { 口YES } \quad \square N O
$$

3. Do you think that the DRE violates men's masculinity?

$$
\text { 口YES } \quad \text { NNO }
$$

4. Are men taught to practice having regular doctor visits in your family?

$$
\text { 口YES } \quad \text { NO }
$$

5. Do you believe men hold a tradition of privacy and pride regarding having a DRE?

$$
\text { 口YES } \quad \text { NO }
$$

6. Do you prefer the use of herbal remedies rather than having a DRE?

$\square Y E S \quad \square N O$

7. Is the social norm pertaining to DRE restraining you from consenting to one?

$$
\square \mathrm{YES} \quad \square \text { NO }
$$

